УДК 343.136:343.18

DOI https://doi.org/10.32849/2663-5313/2020.7.56

\title{
Марина Городецька,
}

канд. юрид. наук,

доцент кафедри кримінально-правових дисииплін та судових експертиз

Донецького юридичного інституту Міністерства внутрішніх справ України

\section{ФУНКЦІОНАЛЬНИЙ ПРЕДМЕТ ВІДАННЯ У КРИМІНАЛЬНОМУ ПРОЦЕСІ}

У статті розглядається функиіональний предмет відання у кримінальному процесі. Визначено, що загальний генеральний предмет відання кримінального процесу поділяється на функиіональні предмети відання. Поділ на функиіональні предмети відання є поділом за змістовим наповненням. У статті зазначено, що реалізачія кримінальних прав входить до змісту усіх уповноважених органів судочинства, але у різній формі. Органи обвинувачення реалізують кримінальне право у формі формулювання обвинувачення, визначення його меж. Остаточне визнання кримінально-правових відносин та остаточна реалізачія кримінального права належить до предмета відання судових органів.

На підставі аналізу діяльності суб'єктів кримінального процесу зазначено, що загальні основоположні права, свободи та законні інтереси особи виступають як предмет відання судових органів, які здійснюють функиію правосуддя. Реалізація кримінальних прочесуальних процедурних прав $є$ змістовим наповненням органів, що здійснюють функиію кримінального переслідування (обвинувачення).

Зроблено висновок, що предмет відання органів обвинувачення становить реалізачія кримінальних та прочесуальних прав людини, яка за характером є підготовчою. Вона створює передумови для реалізачії основних кримінальних та прочесуальних прав людини, а також для остаточного вирішення кримінально-правового конфлікту під час справедливого судового розгляду. Предмет відання судових органів становить остаточна реалізачія кримінальних та основоположсих проиесуальних прав людини під час кримінального провадження та його остаточне вирішення шляхом справедливого судового розгляду.

Визначено, що обсяг функиіонального предмета відання становлять усі права учасників кримінального провадження: 1) права учасників, що відстоюють власний інтерес, 2) права учасників, що представляють інтереси інших осіб, 3) права учасників, які не мають власного інтересу та не представляють інтересів інших осіб.

У результаті дослідження зроблено висновок, що встановлення самих лише прав та обов'язків учасників кримінального провадження не забезпечить ефективного захисту їхніх інтересів. Необхідно враховувати, що їхні права та обов'язки є змістовим наповненням предмета відання суб'єктів кримінального судочинства. Тому ефективний захист законних інтересів учасників залежить від ефективного впливу суб'єктів провадження на «власний» предмет відання. Як правило, такий вплив здійснюється шляхом застосування наданих повноважень суб'єктами кримінального судочинства.

Ключові слова:підслідність, підсудність, предмет відання, повноваження, суб'єкт кримінального провадження, учасники кримінального процесу.

Постановка проблеми. Кримінальному процесу як соціальній системі відповідає загальна сфера публічних справ, яка підлягає вирішенню. Вказана сфера публічних справ є певним загальним предметом відання у кримінальному процесі, який можна назвати генеральним предметом відання. Подальший розподіл генерального предмета відання кримінального процесу відбувається за поділом на кримінальні процесуальні функції. Коли окреслюється певний функціональний предмет відання та визначаються для нього функції, визначаються суб'єкти - органи, які будуть опрацьовувати даний предмет відання у певному напрямі (функція). Правильний розподіл предмета відання у кримінальному процесі сприяє ефективності провадження, підвищенню дієвості кримінальної процесуальної діяльності. Проте у вітчизняному законодавстві та кримінальній процесуальній теорії увага здебільшого приділяється дослідженню та регламентуванню таких понять, як підсудність та підслідність, які не охоплюють предмет відання усіх суб'єктів кримінального процесу.

Аналіз останніх досліджень і публікацій. Окремі аспекти розподілу предмета відання у кримінальному провадженні досліджували такі вчені, як: Ю. М. Грошевий, В. С. Зеленецький, О.В. Капліна, Л. М. Лобойко, С. В. Оверчук, А. А. Омаров, М. А. Погорецький, О. Ю. Татаров, В. І. Шишкін та інші. Проте зміст та обсяг 
функціонального предмета відання у кримінальному процесі такими вченими не розглядалися Тому розгляд функціонального предмета відання залишається актуальним та потребує дослідження.

Метою даної статті є дослідження функціонального предмета відання. Для досягнення цієї мети необхідно виконати завдання: дослідити функціональний предмет відання органів, що здійснюють кримінальне переслідування, дослідити функціональний предмет відання судових органів, дослідити особливості визначення обсягу функціонального предмета відання.

Виклад основного матеріалу. Уявивши кримінальний процес як соціальну систему, можна зрозуміти, що цій системі відповідає певний загальний предмет відання як загальна сфера публічних справ, що підлягають вирішенню. Такий загальний предмет відання у кримінальному процесі можна назвати генеральним предметом відання подібно до того, як В. С. Зеленецький визначив боротьбу зі злочинністю як генеральну функцію кримінального процесу [1, с. 57].

Подальший розподіл генерального предмета відання кримінального процесу відбувається за поділом на кримінальні процесуальні функції. Предмет відання пов'язаний не 3 посадою, а саме 3 певною кримінальною процесуальною функцією. Тому не можливо не погодитися з Л. М. Лобойком, який наголосив на необхідності визначати поняття слідчого не як посади, а саме як функції [2, с. 14].

Коли окреслюється певний функціональний предмет відання та визначаються для нього функції, визначаються суб’єкти - органи, які будуть опрацьовувати даний предмет відання у певному напрямі (функція). Після окреслення функціонального предмета відання розподіляються предмети відання між органами, які здійснюють одну й ту ж кримінальну процесуальну функцію. Тобто предмети відання розподіляються між суб'єктами провадження, тоді як під час визначення функціонального предмета відання розподіл відбувається між, так би мовити, «функціональними сторонами».

Оскільки функція характеризує цілі діяльності, іiі напрям, роль суб'єкта щодо окресленої сфери впливу, то на даному етапі можна казати про змістову різницю у впливі тих суб’єктів, що здійснюють різні функції. Саме на даному етапі поділ на функціональні предмети відання відбувається за критеріями різниці у змісті впливу. А тому і поділ на функціональні предмети відання є поділом за критерієм його змістового наповнення.
На думку О. М. Овчаренко, саме розв'язання правового конфлікту, тобто спору про право, має бути критерієм віднесення певного питання до юрисдикції суду [3, с. 165].

Реалізація кримінальних прав стосується усіх уповноважених органів судочинства, але у різній формі. Якщо органи обвинувачення реалізують кримінальне право у формі формулювання обвинувачення, визначення його меж, то саме остаточне визнання кримінально-правових відносин та остаточна реалізація кримінального права належить до предмета відання судових органів. У контексті розгляду функціональних предметів відання розглянемо також вплив суб'єктів на процесуальні права учасників кримінального провадження, до яких слід віднести конституційні (природні) та суто процесуальні (процедурні) права.

Щодо конституційних прав О. В. Гладишева зазначає, що держава в особі законодавця не дає громадянам права та свободи, але визнає їх наявність, що підкреслює об'єктивність їх існування. Поряд із конституційними авторка виокремлює галузеві права та свободи, у тому числі кримінальні процесуальні, які є похідними від конституційних у своїй більшості і виступають як їх продовження, уточнення. По відношенню до галузевих прав держава в особі законодавця виступає як творець та розробник у сукупності. Щодо кримінальних процесуальних відносин О. В. Гладишева підкреслює, що процесуальними правами особа наділяється в установленому законом порядку, тоді як конституційними правами вона володіє. Тому, на думку вченої, стосовно кримінального судочинства законодавцю належить не лише передбачувати права та свободи особи, але і визначити процесуальний порядок наділення ними (підстави набуття прав та свобод у кримінальному судочинстві, порядок діяльності суб'єктів, уповноважених наділяти правами тощо) [4, с. 110].

Аналізуючи діяльність суб'єктів кримінального процесу, можна припустити, що загальні основоположні права, свободи та законні інтереси особи виступають предметом відання судових органів, які здійснюють функцію правосуддя. Оскільки саме судові органи вирішують питання, які стосуються втручання у загальні права та свободи особи. Відповідно, реалізація кримінальних процесуальних процедурних прав є змістовим наповненням органів, що здійснюють функцію кримінального переслідування (обвинувачення).

Не можна говорити, що предмет відання судових органів не включає реалізацію кримінальних процесуальних процедур- 
них прав, проте сама специфіка їх предмета відання полягає у реалізації основних прав та свобод. Тут спрацьовує правило, що суб'єкт вищого компетенційного рівня може виходити за межі компетенції за рівнем нижче, але не навпаки. Суб'єкт вищого компетенційного рівня має справу з результатом роботи суб'єкта нижчого рівня, тому закон вважає першого «компетентним» для втручання у діяльність другого [5]. Судові органи є суб'єктами вищого компетенційного рівня стосовно органів обвинувачення Під час судового розгляду процедурні права прокурора як представника сторони обвинувачення реалізуються через судові органи так само, як і сторони захисту.

Суб'єкти обвинувачення у своїй діяльності прагнуть до застосування норми кримінального права - визнати особу винною у вчиненні кримінального правопорушення, приводом до чого є вчинене протиправне кримінально карне діяння. Проте органи обвинувачення позбавлені можливості самостійного застосування норми кримінального права, щоб уникнути можливого з їхнього боку свавілля. Остаточне застосування кримінально-правової норми покладається на суд. Таким чином, суд обмежує органи обвинувачення в остаточному застосуванні норми кримінального права. Лише суд визнає людину винною перед державою за вчинення кримінального правопорушення та призначає покарання. Суд стримує державу у здійсненні нею обвинувачення особи через діяльність її уповноважених органів, причому як в обвинуваченні остаточному (застосування норми кримінального права), так і в обвинуваченні у значенні обвинувальної діяльності, а саме у безпідставному (свавільному) обмеженні прав людини під час кримінального переслідування.

Можна зазначити, що головним завданням кримінального процесу як визначеної державою процедури є остаточна реалізація кримінального права, тобто застосування кримінальної норми 3 передбаченою у ній санкцією - покаранням. Але реалізація кримінального права має відбуватися не абияк, а справедливо, що є передумовою виникнення права на справедливий судовий розгляд. Отже, кримінальний процес вирішує завдання, кримінально-правовим елементом якого є остаточна реалізація норми кримінального права, а кримінальним процесуальним елементом $є$ забезпечення справедливого судового розгляду, у процесі якого відбувається реалізація норми кримінального права.

Загальна мета діяльності органів обвинувачення відбивається на визначеному для них предметі відання. Вони здійснюють вплив на реалізацію кримінальних прав у тій частині, яка є необхідною для остаточної реалізації кримінального права та вирішення кримінально-правового конфлікту судом. Так само й щодо реалізації процесуальних прав: органи обвинувачення впливають на реалізацію лише процесуальних процедурних прав, що створює передумови для реалізації основоположних прав та свобод людини, у тому числі права на справедливий судовий розгляд, справедливе вирішення конфлікту.

Подібно до того як на судові органи покладено остаточний справедливий розгляд у справі, своєю чергою на органи обвинувачення покладене ефективне розслідування, тобто ефективне «готування» до судового розгляду, що $€$ його передумовою. Щоб забезпечити справедливий судовий розгляд, це «готування» має відповідати певним стандартам забезпечення прав людини. Окремо такі стандарти ефективного розслідування ми розглядали у попередніх публікаціях [6].

Отже слід зробити висновок, що предмет відання органів обвинувачення становить реалізація кримінальних та процесуальних прав людини, яка за характером є підготовчою. Вона створює передумови для реалізації основних кримінальних та процесуальних прав людини, а також для остаточного вирішення кримінально-правового конфлікту під час справедливого судового розгляду.

Предмет відання судових органів становить остаточна реалізація кримінальних та основоположних процесуальних прав людини під час кримінального провадження та його остаточне вирішення шляхом справедливого судового розгляду.

Кримінальний процес не завжди завершується вироком або іншим судовим рішенням. Рішення про завершення кримінального процесу під час досудового розслідування може бути прийняте органами обвинувачення. Це цілком узгоджується з тим, що у процесі підготовчої діяльності з реалізації кримінальних та процесуальних прав встановлюється відсутність підстав для реалізації таких прав.

Обсяг функціонального предмета відання сторони обвинувачення становлять процесуальні (процедурні) права учасників кримінального провадження. Причому переважно на стадії досудового розслідування, оскільки під час судового розгляду реалізація процесуальних прав представників кожної зі сторін провадження залежить від суду.

Змістовно функціональний предмет відання є однаковим (єдиним) для усіх органів обвинувачення. Їхня компетенція різниться наданими повноваженнями, а предмет відання поділяється за темпоральними межами. 
Загальний обсяг функціонального предмета відання сторони обвинувачення становить уся сукупність процесуальних прав та обов'язків учасників кримінального провадження. Як зазначено вище, враховуючи, що кожному праву кореспондує обов'язок i навпаки, іх сукупність можна виражати через «правообов'язок», або вести мову лише про права, маючі на увазі, що кожному такому праву відповідає певний обов'язок. Реалізація більшості вказаних процесуальних прав віддана під вплив органів кримінального переслідування саме на досудовому розслідуванні, оскільки у судовому провадженні реалізація процесуальних прав учасників відбувається за умови правозастосовної діяльності суду.

Отже, фактично обсяг функціонального предмета відання становлять усі права учасників кримінального провадження: 1) права учасників, що відстоюють власний інтерес, 2) права учасників, що представляють інтереси інших осіб, 3) права учасників, які не мають власного інтересу та не представляють інтересів інших осіб.

Враховуючи, що визначені права та обов'язки учасника становлять його правовий статус у кримінальному процесі, можна зазначити, що кожного разу, коректуючи статус, додаючи або «віднімаючи» певні права чи обов'язки, законодавець тим самим коректує предмет відання суб'єктів кримінального провадження.

Щодо обсягу прав підозрюваного, обви нуваченого та потерпілого Н. М. Апостолова зазначає, що у разі застосування принципу доцільності обсяг прав вказаних учасників має бути таким, котрий дозволить їм ефективно захищати свої законні інтереси [7, с. 41].

Не можна не погодитися 3 позицією авторки. Проте не можна не враховувати, що ефективний захист інтересів залежить також від впливу правозастосовних органів на встановлені права учасників. Тут має враховуватись конструкція компетенції суб'єктів кримінального судочинства: наділяючи певного суб'єкта визначеним предметом відання, задля виконання покладеної на нього функції йому мають бути надані певні повноваження для впливу на предмет відання, щоб досягти бажаної мети, яка визначається його функцією. Тому встановлення самих лише прав та обов'язків учасників кримінального провадження не забезпечить ефективного захисту їхніх інтересів. Необхідно враховувати, що їхні права та обов'язки є змістовим наповненням предмета відання суб'єктів кримінального судочинства. А тому ефективний захист законних інтересів учасни- ків залежить також від ефективного впливу суб'єктів провадження на «власний» предмет відання. Як правило, такий вплив здійснюється шляхом застосування наданих засобів впливу - повноважень суб'єктів кримінального судочинства.

A тому ефективний захист законних інтересів учасників кримінального провадження $є$ результатом поєднання встановлення доцільного обсягу процесуальних прав учасників з огляду на формування їхнього процесуального статусу та з огляду на формування предмета відання уповноважених органів з урахуванням повноважень останніх як ефективних засобів впливу.

\section{Висновки}

Виходячи з вищезазначеного, маємо такі висновки:

1. Предмет відання органів обвинувачення становить реалізація кримінальних та процесуальних прав людини, яка за характером є підготовчою. Вона створює передумови для реалізації основних кримінальних та процесуальних прав людини, а також для остаточного вирішення кримінально-правового конфлікту під час справедливого судового розгляду.

2. Предмет відання судових органів становить остаточна реалізація кримінальних та основоположних процесуальних прав людини під час кримінального провадження та його остаточне вирішення шляхом справедливого судового розгляду.

3. Ефективний захист законних інтересів учасників кримінального провадження $€$ результатом поєднання встановлення доцільного обсягу процесуальних прав учасників з огляду на формування їхнього процесуального статусу та з огляду на формування предмета відання уповноважених органів 3 урахуванням повноважень останніх як ефективних засобів впливу.

Перспективами подальших розвідок у даному науковому напрямі можуть стати такі: дослідження обсягу та меж предмета відання, висвітлення елементів предмета відання у кримінальному процесі.

\section{Список використаних джерел:}

1. Зеленецкий В.С. Возбуждение государственного обвинения в советском уголовном процессе. Харьков: Вища школа, 1979. 144 с.

2. Лобойко Л.М. Пригоди Європейських стандартів судочинства у кримінальному процесі після 20 листопада 2013 року. Європейські стандарти кримінального судочинства : матеріали Всеукр. наук.-практ. конф. (м. Донецьк, 27 вересня 2013 року). Донецьк: ДЮІ МВС України, 2014. C. $12-15$. 
3. Овчаренко О.М. Доступність правосуддя та гарантії його реалізації : монографія. Харків: Право, 2008. 304 с

4. Гладышева О.В. Теоретические основы обеспечения законных интересов личности в уголовном судопроизводстве. Москва: Юрлитинформ, 2012. 192 с.

5. Городецька М.С. Межі кримінально-процесуальної компетенції слідчого органів внутрішніх справ. Актуальні питання державотворення в Украӥні очима молодих учених : матеріали міжнародної науково-практичної конференції студентів, аспірантів та молодих учених Київського національного університету імені Тараса Шевченка (23-24 квітня 2009 року). Київ, 2009. Ч. IV. С. 197-199.

6. Городецька М.С. Окремі стандарти ефективного розслідування. Роль права та закону у громадянському суспільстві : матеріали Міжнародної науково-практичної конференції (м. Одеса, Україна, 20-21 квітня 2012 р.). Одеса: у 3-х частинах. Одеса: ГО «Причорноморська фундація права», 2012. ч. 3. С. 92-94

7. Апостолова Н.Н. Целесообразность (дискреционность) в российском уголовном судопроизводстве : дис. ... д-ра. юрид. наук: 12.00.09. Москва, 2010. 369 с.

Marina Horodetska. Functional subject of jurisdiction in criminal proceedings

The article considers the functional subject of jurisdiction in criminal proceedings. It is determined that the general subject of criminal proceedings is divided into functional subjects of jurisdiction. The division into functional subjects of jurisdiction is the division according to the content. The article states that the implementation of criminal rights is included in the content of all authorized bodies of justice, but in different forms. Prosecution authorities implement criminal law in the form of formulating charges, defining its boundaries. The final recognition of criminal law relations and the final implementation of criminal law is the subject of judicial jurisdiction.

Based on the analysis of the activities of the subjects of criminal proceedings, it is stated that the general fundamental rights, freedoms and legitimate interests of the person act as the subject of jurisdiction of the judicial bodies that perform the function of justice. The implementation of criminal procedural rights is a meaningful content of the bodies that perform the function of criminal prosecution (prosecution).

It is concluded that the subject of the prosecution is the implementation of criminal and procedural human rights, which is preparatory in nature. It creates the preconditions for the realization of basic criminal and procedural human rights, as well as for the final resolution of criminal law conflicts in a fair trial. The subject of jurisdiction of the judiciary is the final realization of criminal and fundamental procedural human rights during criminal proceedings and its final solution through a fair trial.

It is determined that the scope of the functional subject of jurisdiction is all the rights of participants in criminal proceedings: 1) the rights of participants defending their own interests, 2) the rights of participants representing the interests of others, 3) the rights of participants who do not have their own interests and do not represent the interests of others persons.

The study concluded that the mere establishment of the rights and obligations of participants in criminal proceedings will not provide effective protection of their interests. It should be borne in mind that their rights and responsibilities are meaningful content of the subject matter of the subjects of criminal proceedings. Therefore, the effective protection of the legitimate interests of the participants depends on the effective influence of the subjects of the proceedings on their "own" subject matter. Typically, such influence is exercised through the exercise of powers by the subjects of criminal proceedings.

Key words: investigative jurisdiction, jurisdiction, subject of jurisdiction, public authorities, subject of criminal proceedings, participant in criminal proceedings. 